\title{
New Florida Foliage Plant Cultivar: Aglaonema “Leprechaun”
}

\section{R. J. Henny and J. Chen ${ }^{2}$}

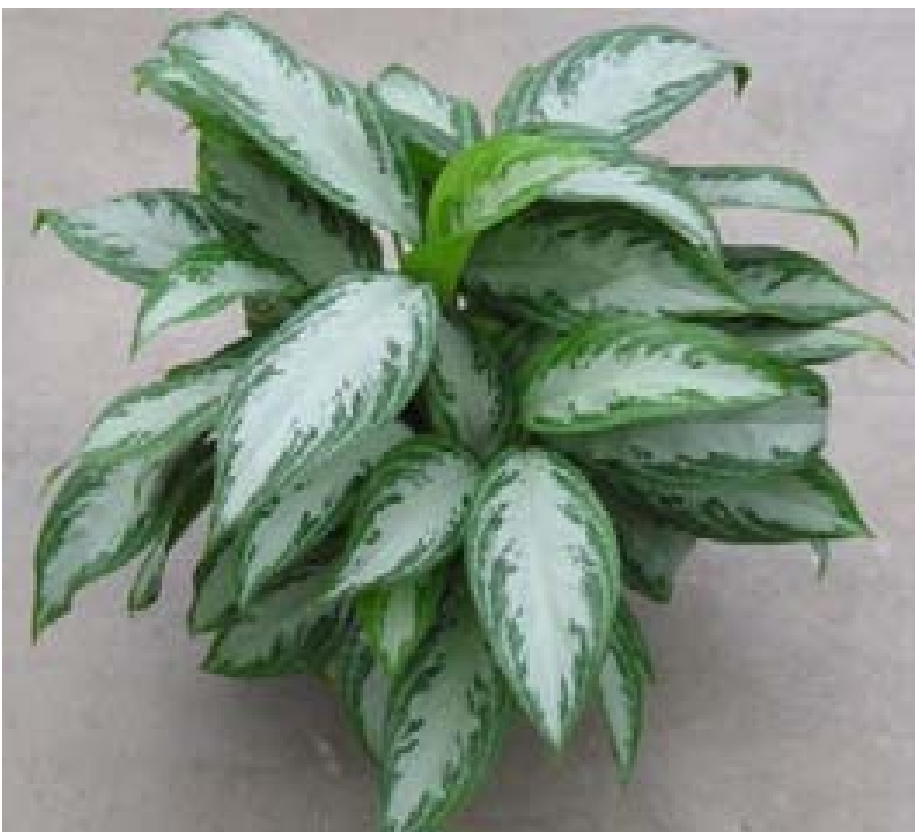

Figure 1. A mature Aglaonema 'Leprechaun' grown in a 6-inch (1.6 L) container

\section{Origin}

Aglaonema are commonly called Chinese evergreens, and Aglaonema cultivars (in the Araceae plant family) make up an economically important sector of the tropical foliage plant industry in Florida. Aglaonema 'Leprechaun' (Figure 1) developed as a whole-stem mutation that was found within a large population of Aglaonema 'Silver Bay' plants. Aglaonema 'Leprechaun' exhibited the same foliar variegation as the parent but was dwarf, more highly branched, and grew in a rounder overall form when compared to Aglaonema 'Silver Bay' (Figure 2). Aglaonema 'Leprechaun' was isolated, propagated by tip cuttings, and evaluated for a 3-year period. After testing by the University of Florida's Foliage Plant Breeding Program at the MidFlorida Research and Education Center (MREC) in Apopka and following grower trials, the mutation was determined to be stable and suitable as a new cultivar.

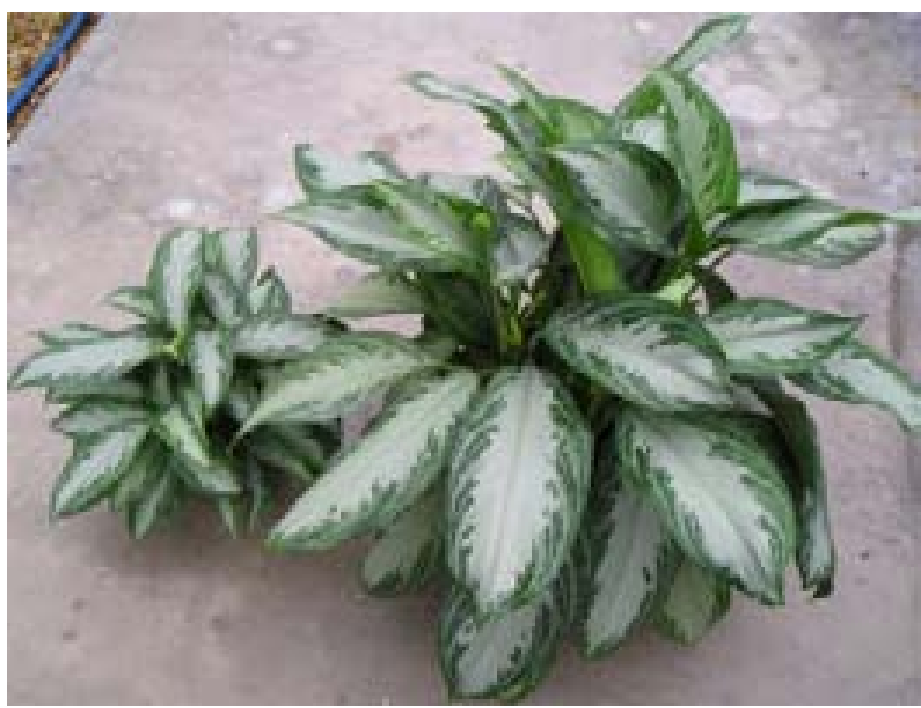

Figure 2. Aglaonema'Leprechaun' (left) is smaller than its parent Aglaonema'Silver Bay' (right).

1. This document is ENH1 185, one of a series of the Environmental Horticulture Department, Florida Cooperative Extension Service, Institute of Food and Agricultural Sciences, University of Florida. Original publication date August 2011. Visit the EDIS website at http://edis.ifas.ufl.edu.

2. R. J. Henny and J. Chen, professors, Mid-Florida Research and Education Center - Apopka, University of Florida Institute of Food and Agricultural Sciences, Gainesville, FL 32703 
Ten Aglaonema cultivars have been released by the Foliage Plant Breeding Program (Henny and Chen 2001, 2008, 2009, 2010; Henny et al. 1988, 1992a, 1992b, 2003, 2008).

'Leprechaun' is the eleventh named cultivar to be developed and selected. Aglaonema 'Leprechaun' was released due to its compact size, attractive foliage, excellent growth habit, and outstanding performance in interior conditions.

\section{Description}

Aglaonema 'Leprechaun' grows in a compact form and has a symmetrically rounded plant habit. New leaves are initially upright, then arch outward and downward as they develop. Leaves are lance shaped; an average mature leaf is approximately $20 \mathrm{~cm}$ (8 inches) long and approximately $7 \mathrm{~cm}(2.7$ inches) wide. The upper surfaces of mature fully expanded leaves are yellow green to light green. The center area of the leaf is gray green and extends out from the midrib toward the leaf edge in an irregular pattern more than halfway on each side. The midrib itself and the primary veins are gray green. The lower surface of fully expanded leaves is yellow green. The lower surface midrib and veins are yellow green. The leaf margin is smooth (entire), and leaf tissue (lamina) on either side of the midrib tends to be of unequal widths, resulting in a slight curving of the leaf blade toward the narrower side. The petiole color is overall yellow green; the petiole area immediately adjacent to the stem is white (Figure 3). The inner petiole wing is yellow green, whereas the outer petiole wing surface is lighter yellow green. The petiole wing area adjacent to the stem is white. Plants grown from a single cutting branch very well, averaging over 10 basal shoots each.

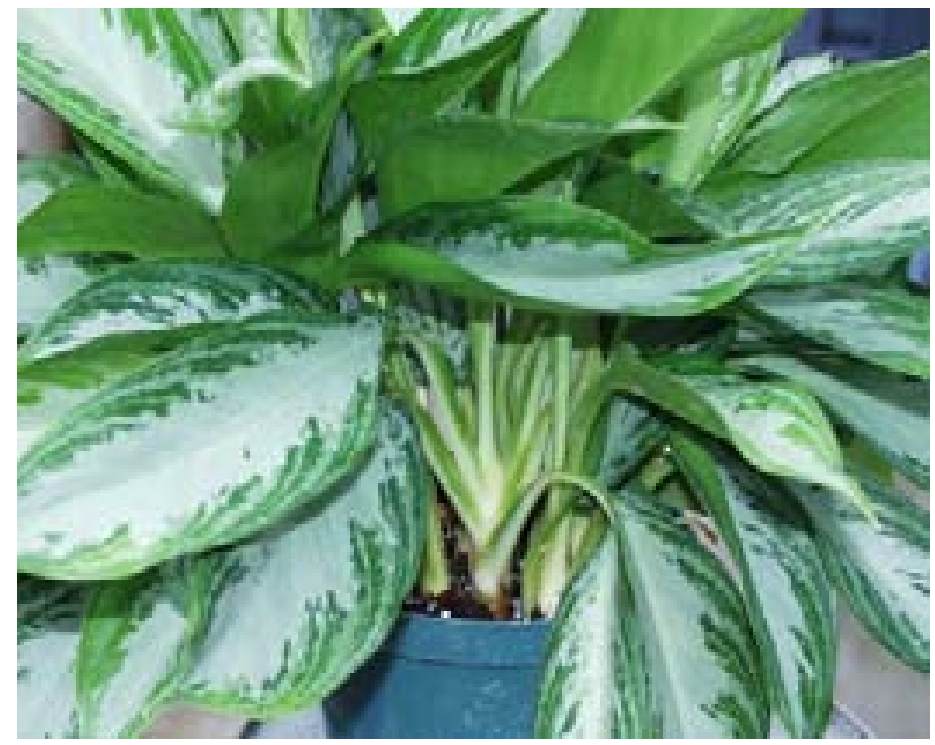

Figure 3. The petiole color of Aglaonema 'Leprechaun' is yellow green overall. The petiole wing color adjacent to the stem is white.

\section{Performance}

Growth tests were initiated using $12-15 \mathrm{~cm}$ (5-6 inch) long tip cuttings that held 3-4 leaves each. Cuttings were harvested from Aglaonema 'Leprechaun' stock plants grown in a shaded greenhouse (70\% shade)and stuck in 50 -celled trays containing Fafard \#2 Mix (Conrad Fafard Inc, Agwam, MA), consisting of 55\% Canadian peat: $25 \%$ perlite: and $20 \%$ vermiculite. The cuttings were placed inside a propagation tent for 8 weeks. Once outside the tent, the rooted cuttings were allowed to acclimatize for 2 additional weeks. At that time, 30 uniform rooted liners were selected and potted in 6-inch-diameter $(1.6 \mathrm{~L})$ pots using Fafard \#2 soil mix. Plants were grown in randomized block experimental design in a shaded greenhouse under $70 \%$ shade in natural photoperiod with a temperature range of $15^{\circ} \mathrm{C}-34^{\circ} \mathrm{C}\left(60^{\circ} \mathrm{F}-92^{\circ} \mathrm{F}\right)$. Plants were grown using 3 ,

5 , or 7 g per container of Nutricote ${ }^{\circledR}$ Plus $18 \mathrm{~N}-2.6 \mathrm{P}-6.6 \mathrm{~K}$ (Chisso-Asahi Fertilizer Co., Ltd, Tokyo, Japan). Ten plants per each fertilizer treatment were grown in a completely randomized design for 9 months. Plants were handwatered as necessary and fertilizer was reapplied every 3 months.

Data recorded at termination of the study included canopy height, canopy width, length and width of the largest leaf, number of basal shoots, and a visual quality rating, where 1 = poor, 2 = fair (not saleable), 3 = acceptable (saleable), $4=$ good quality, and $5=$ excellent quality. Finished plants were moved into an interior growth room for 3 months under a light level of 100 foot-candles for 12 hours daily at a constant $26^{\circ} \mathrm{C}\left(80^{\circ} \mathrm{F}\right)$. A second visual quality rating was measured following 3 months in the interior growth room conditions. Data were analyzed using ANOVA procedures of the SAS program (SAS Institute Inc., Cary, NC).

\section{Results}

Aglaonema 'Leprechaun' grown in 6-inch $(1.6 \mathrm{~L})$ pots reached marketable size in 9 months. Fertilizer levels did not significantly affect canopy height, canopy width, pulledup height, leaf width, or number of basal shoots or plant quality (Table 1). There was a significant linear decrease in leaf length as fertilizer levels increased; however, the differences had no visual effect on appearance or quality. Plant quality rating averaged good to excellent at all nutritional levels. After 3 months of interior room testing, all plants graded out as excellent (data not presented).

\section{Availability}

Aglaonema 'Leprechaun' is trademarked and patented by the United States Patent and Trademark Office (PP\# 
19,714). Plant patent rights are assigned to the University of Florida Board of Trustees. Commercial foliage plant growers can obtain licensed stock for Aglaonema 'Leprechaun' through Florida tissue-culture laboratories. Names of cooperating laboratories may be obtained from the Florida Foundation Seed Producers, P.O. Box 309, Greenwood, FL 32443. Its compact growth habit and dense branching make Aglaonema 'Leprechaun' suitable for production in 6-inch-diameter $(1.6 \mathrm{~L})$ or 8 -inch $(3.9 \mathrm{~L})$ pots. Inquiries regarding licensing may be sent to Florida Foundation Seed Producers, Inc., P.O. Box 110200, Gainesville, FL 32611.

\section{Additional Information}

Henny, R. J., and J. Chen. 2001. "Aglaonema 'Golden Bay'."

HortScience 36:1142-1143

Henny, R. J., and J. Chen. 2008. "'Moonlight Bay' Agla-

onema." HortScience 43(5): 1598-1599.

Henny, R. J., and J. Chen. 2009. "'Key Lime' Aglaonema."

HortScience 44(6): 1767-1768. 2009.

Henny, R. J., and J. Chen. 2010. "'Scenic Bay' Aglaonema."

HortScience 45:1281-1282.

Henny, R. J., J. Chen, T. A. Mellich, and M. S. Brennan. 2008. "'Mondo Bay' Aglaonema." HortScience 43(6):

1900-1901.

Henny, R. J., J. Chen, and D. J. Norman. 2003. "Aglaonema 'Diamond Bay' and 'Emerald Bay'." HortScience 38:1446-1447.

Henny, R. J., R. T. Poole, and C. A. Conover. 1988. "'Stripes' Aglaonema." HortScience 23(95): 920-921.

Henny, R. J., R. T. Poole, and C. A. Conover. 1992a. "'Flamingo' Aglaonema." HortScience 27(10): 1139

Henny, R. J., R. T. Poole, and C. A. Conover. 1992b. "'Silver Bay' Aglaonema." HortScience 27:1238. 
Table 1. Characteristics of Aglaonema 'Leprechaun' after 9 months' growth in 6-inch (1.6 L) pots

\begin{tabular}{|c|c|c|c|c|c|c|}
\hline \multirow{2}{*}{$\begin{array}{l}\text { Nutricote }{ }^{\circledR z}(\mathrm{~g} / \\
\text { pot } / 3 \text { months) }\end{array}$} & \multicolumn{2}{|c|}{ Canopy } & \multicolumn{2}{|c|}{ Largest leaf } & \multirow[t]{2}{*}{ Basal shoots (no.) } & \multirow[t]{2}{*}{ Visual quality ${ }^{y}$} \\
\hline & Height (inches) & Width (inches) & Length (inches) & Width (inches) & & \\
\hline 3 & 9.3 & 15.3 & 7.9 & 3.0 & 11.1 & 4.8 \\
\hline 5 & 9.0 & 15.4 & 7.7 & 2.8 & 10.1 & 4.5 \\
\hline 7 & 8.9 & 14.4 & 7.4 & 2.8 & 10.6 & 4.5 \\
\hline Significance $^{\mathrm{x}}$ & NS & NS & $L^{*}$ & NS & NS & NS \\
\hline
\end{tabular}

${ }^{z}$ Nutricote ${ }^{\circledR}=18 \mathrm{~N}-2.6 \mathrm{P}-6.6 \mathrm{~K}$ (g/pot $/ 3$ months). One level teaspoon $=\sim 5.0 \mathrm{~g}$.

'Visual quality, where 1 = poor, $2=$ fair, $3=$ saleable, $4=$ good, and $5=$ excellent quality.

${ }^{\times}$Regression analysis, where NS = not significant and $\mathrm{L}^{*}=$ linear significance at $5 \%$ level. 